\title{
The Place of the Artist
}

\author{
Kevin Bott \\ Wagner College
}

I'm trying to stay with the grief.

There's an anecdote about the Dalai Lama, probably apocryphal, which I've always thought profound. Upon being asked to offer his reflections on the state of the world, the Dalai Lama presumably said nothing. He simply began weeping.

Sometimes, like in yet another meeting, which is actually a pre-meeting to some other meeting we're going to have in a couple of weeks at which time we're likely to make a decision about an event speaker, or which classes count for the general education requirement... Sometimes, in such contexts, I feel like weeping.

I'll sit there, and I'll scan the faces at the table, and I'll think about the suffering that's happening right then, at that very moment, all around the world. All the trauma being experienced, all the pain. Some child, somewhere, at the very same time we're meeting, who should be in school but who's instead sifting through other people's recycling. Some woman, right now, getting punched in the gut or in the face for saying the wrong thing. Abuse. Neglect. Hunger. Young girls, children, being sold as sex slaves. Brutal, unimaginable torture. I think about the environment and my powerlessness to save it. I think about the fact that we're on a speeding train, hurtling ourselves with evermore urgency toward death. All. Right. Now.

And then I'll look down at the general education requirements and I'll feel a sudden jolt of emotion. A lump in my throat. Tears stinging my lower eyelids. No one notices but I do it, I begin to cry.

What are we doing, I'll ask myself? What are we all doing here?

Could I stick my index finger in the air at that moment? Is it appropriate, would it be ok, to ask if we could step back from the requirements for just a second and acknowledge that this meeting is happening aboard a hurtling train? Could we give a shout out to the melting ice caps and the warming oceans? Could we give a nod to the super storms and the climate refugees? Before we decide on the gen. ed. thing, might we mention the bursting pipelines and the hydrofracking earthquakes and the oil pouring into our seas?

But listen, if it's too much to confront the envi- ronmental end times thing, let's at least agree to acknowledge the death of liberal democracy and the rise of authoritarianism and oligarchy around the world, including right here in the good ole' U.S. of A. I mean, if we're going to talk about the "general education" that every one of our graduating students should receive, those are the two first order priorities, right? The death of our planet and the mutually reinforcing dynamics of predatory capitalism's rise and democracy's decline? And shouldn't we be asserting the importance, too, of all of our students understanding the effects of these first order priorities: mass incarceration and the rise of the police state; disinvestment from public education and the arts; poverty and food shortages; resource scarcity; addiction; health disparities defined by race and class; exploitation; inequity? And finally, do have anything to say about the mental and emotional anguish that arises from all of that - the dark energies driving us deeper toward some kind of abyss: isolation; distrust; suspicion; fear; intolerance; greed; violence; hatred. Ultimately, nihilism: a deep skepticism that anything has meaning?

What would happen, I wonder at times like these, if I just started quietly weeping. I think I'm wellliked at work. I don't have a reputation for being unhinged or hysterical or anything. I wear a suit and tie everyday. I'm an administrator for god's sake. What if I just started crying?

What if the provost started crying? What if the president did it, say, at the trustees meeting? What if my students started to break down. Just wept at the absurdity of it all. Inconsolable ... ?

I'm trying to stay with the grief.

\section{Thinking about Democracy}

I'm the dean for civic engagement at Wagner College, a small liberal arts college in New York City. I grew up performing in and directing theater, mostly musicals, and then went to graduate school where I studied something called communitybased theater, a sub-discipline of traditional theater arts which focuses on the collaborative process of creating performance with and for specific com- 
munities who are interested in explorng issues of shared concern through creative means. To become a community-based theater artist is to become a civically-engaged professional. A gift I've received from my field, and from my association with civic engagement in higher education, has been the invitation to think more deeply about democratic culture.

In this latter capacity, my class has been studying early American democracy using the musical, Hamilton, as a starting point. We've been talking about the importance of strong institutions to the practice of democracy - K-12 schools and colleges, courts, religious institutions, local governments - and how the presence of such institutions provided an infrastructure that facilitated a fairly seamless transition from British to American rule after the revolution. We've also been thinking about the nature and function of these institutions today, grounded in our sense that the future of democracy is in question.

The major cracks in democracy's facade that we are currently witnessing are not caused by the absence of strong institutions today but rather a proliferation of institutions that are, as Zlotkowski writes of higher education, "inert" (1995, p. 1). Or, to put it another way: dead. The question today is not, as he posed it 20 years ago, whether service-learning has a future; it's whether higher education has a future, it's whether American democracy and, incredibly, even our human civilization have futures.

I think about all of this within a contemporary context wherein many democratic institutions, including institutions of public K-12 and higher education, have lost both the public trust and a vision of themselves as spaces for the advancement of democracy and democratic culture - or, if not the vision, at least the modus operandi. There are many reasons for this - most of them beyond the scope of this article - but I find myself focusing on the likelihood that the values inherent to civic culture simply don't mix well with those inherent to capitalism or at least to the kind of deregulated, predatory, "casino capitalism" (Giroux, 2011) that has come to have undue influence on institutions of both finance and government in the United States. The former proposes a balance between individual and societal gain, between the fortunes of the self and those of the commonwealth. The latter sees everything as a zero sum proposition, wherein everyone is in competition for limited resources, and you getting more means me getting less. The results of such an all-against-all, survival of the fittest approach are what we see now: the rich, investing class gets richer while the rest of us run in place, or fall behind. A crass, hollowed out anti-culture in which one's pub- lic value is measured in direct proportion to one's ability to consume. The rewards of democracy, which are slow and distributed, can hardly compete with those of competitive capitalism, which are fast and . . all mine. So, too, the fears: While the loss of wealth is personal, painful, and immediate, the decline of civic culture is generalized, abstract, and a long way off . . . Until it's not. Until, you discover that, like the rotted insides of a cancer-ravaged body, the living part of the democratic culture is already dead.

\section{The Place of the Artist}

John F. Kennedy, in his remarks at Amherst College on the occasion of the dedication of the Robert Frost Library, said:

If sometimes our great artists have been the
most critical of our society, it is because their
sensitivity and their concern for justice, which
must motivate any true artist, makes him aware
that our Nation falls short of its highest poten-
tial. I see little of more importance to the future
of our country and our civilization than full
recognition of the place of the artist.

I'm sure to most, it will seem hyperbole at best, or naively romantic at worst, to suggest that art is our last, best hope to restore human relationships, institutions, and the planet. But this is exactly what I argue. To marginalize artistry from our institutions and from our lives, as we have done in so many ways - from discouraging our children's innate creativity in favor of more career-relevant preparation, to federal and state level defunding of the arts - is to marginalize the very thing that makes us human and elevates us beyond our savage ancestral roots. Mechanization, administrative bureaucracy, and "objective" performance assessments define the current age. Such an extended moment of dehumanization can only be remedied by humanization, full humanization, which will pull many of us, perhaps especially academics, far outside of their training, their conditioning, and their comfort.

Our schools - public K-12 as well as our colleges and universities - are bureaucratic, managerial, and - with many exceptions, carved out by courageous educators and students - joyless and numb. One might say they're dead. It's often hard to see until one experiences its opposite. I was in Milwaukee recently and visited an after-school program for urban teens called True Skool (http://www.trueskool. org/). I thought, This is what an educational system would look like if it were alive! Show up at 4 o'clock on any afternoon and you'll find a space filled with energetic, engaged, enthusiastic teenag- 
ers. In one room, kids are editing films they created themselves, about life with their families and in their communities. In another, they're creating silkscreens. In another, they're writing and performing spoken word poems or hip-hop verses they penned themselves, on topics they care about. The walls are colorful, filled with high quality artwork, all of it made by current or former students. The atmosphere is infused with energy and passion. Educators like Fidel Verdin and Shalina Ali hop from station to station, answering questions, commenting, offering advice or technical assistance. The teens happily do the same for one another, and more than once I heard a student tell his friend that something they made was "dope" or "hype." Fist bumps and smiles abound, underscoring the sense of collaboration and support. In the spoken word area, they snap after each performance, showing their approval like they were in a 1950s Beat café.

It is, truly, a true school. A place that is responsive rather than reactive, relational rather than transactional, and attuned personally to the interests, gifts, and values of the students rather than connected to them only through levers of administration to address their perceived deficits. It is a place that elevates and celebrates individuality in the context of community, foregrounding how your gifts can elevate yourself and the people you love and care about. Of course, in their regular schools, many of these young people are the "problem" kids. They're disruptive. They're asked to sit at their desks for long stretches, reading histories that seem abstract and irrelevant, developing skills meant to improve standardized test scores. In short, they're educated in ways far removed from their lived experience. They're failing out. But as everyone who actually works in or studies in schools knows, it's the system that's failing the kids, not the other way around.

The schools and other institutions that served democracy 250 years ago - grounded in the rational, empirical values of the Enlightenment - are no longer enough. And in fact, if you ask the many people and groups long excluded from democratic culture - women, people of color, the poor - it's clear they never were enough. What we need in the present age is what the True Skool's got: song and poetry, paint and laughter, celebration, and an emphasis on the complementary aspects of individuality and community. Teachers who encourage students to bring their full selves into the room and support them in learning the work of the citizen artist: how to take the raw materials of life and arrange them in ways that communicate in multi-layered and nuanced ways.

I can speak from my own experience growing up in the nurturing theater environment, both in my hometown and at a nearby summer stock company. I can also speak for the many young people who I've been privileged to direct over the years. When young people are invited to be their full selves, when they are encouraged to be fully human despite the dehumanizing forces all around them, they learn to bring all of their questions and all of their dreams with them into their lives and their interactions. And they - we - also bring our fears, our rejections, and our loss. We learn it's ok, in fact encouraged, that we bring our tears to the table (as anyone who has ever seen me speak publicly can attest).

Walter Brueggeman (1978), in his seminal work, The Prophetic Imagination, names grief as the essential expression of humanity needed to interrupt and ultimately begin to dismantle the inert, lifeless status quo, the "royal consciousness," which masks, with a joyless façade of celebration and excess, the suffering and death at the heart of the culture. Grief, that humble song of lamentation, has a uniquely awesome power to short-circuit the rational structures that hold the whole painful illusion in place. And as anyone who has experienced profound loss knows, it is only when we surrender to grief's demands that we can ever hope to discover the new life, previously unimaginable, to follow.

What would it mean to admit grief into our public institutions? When given room for expression, grief opens channels between us in the places where anger, fear, and argumentation construct walls. When people are given permission to descend into their grief, permitted to weep at all that's been lost and all that will be lost, only then can we begin to imagine alternative possibilities beyond. In Brueggemann's (1978) framing, the work of the prophetic imagination - the lonely voice naming aloud, and lamenting, the rot at the heart of the status quo - is, first, to invite people to experience the collective, too-often-unexpressed grief. Then, in the midst of grief, the task is to invite people to imagine and articulate an energizing and hopeful vision of the future, "to bring to public expression those very hopes and yearnings that have been denied so long and suppressed so deeply that we no longer know they are there" (p. 65).

\section{Grief and Renewal}

So what to do? What might it look like to invite both grief and energizing visions? What can I share, as an artist and civic engagement person, with members of the higher education community who will look askance at the suggestion that they need to get artistic, let alone invite grief?

Joseph Beuys (Tisdall, 1979) famously pro- 
claimed in his 1975 performance/lecture of the same name, Jeder Mensch ist ein Künstler: Every man is an artist. Which is to say that to be human is to possess the power to imagine and to create. Not just within the frame of a canvas or on a stage, but within each moment of our lives. Each interaction with one another and with our environment is an opportunity for artistry - for imagining and creating something new, something that has never been before and can only come into being with our participation. I feel that our work within institutions is to invite one another - students, faculty, staff, and community partners - to be fully human. Not to replace all of the work that's happening but rather to allow for other realities to intrude upon our agendas and lesson plans and to allow for the possibility that those other realities will alter them. We need institutions that are not objective and removed, but involved and truly engaged. It's only then that we're going to understand how to move forward, how to fuel a renaissance.

Let me offer two simple suggestions. First, admit the possibility that rational, logical, linear thinking is just one - not the only - way of understanding, and that it produces particular outcomes, which we know quite well. Admit the possibility that relying exclusively, or even primarily, on rationality and logic has, for all the wonders and conveniences it has produced, also played a not insignificant part in bringing humankind to the brink of its own destruction. Then, perhaps, in every institutional setting where logic, rationality, and linear thinking are the accepted means of moving forward, invite people trained in other modalities to bring their methods and their ways of working into the room. Experiment with giving over one out of every, say, four strategic planning meetings, budget meetings, staff meetings, or lectures to a creative, embodied, or relational approach. Allow for the possibility that people trained in expressive, non-linear, relational ways of thinking and being could help catalyze new approaches and help create the conditions for imagining new ways of being an institution.

But secondly, I want to re-emphasize that, per Beuys, artistry is not the sole province of "artists;" it is ours, as human beings, as a birthright. And one of the most accessible vehicles for humans' innate artistry is storytelling. Through my work in community and at Imagining America I've found that the simplest way to begin moving out of our personal and institutional comfort zones is to make space for stories. It's that simple. Whether you're a faculty member, in any discipline, or a staff member in any unit, or an administrator, or a student leader, or a community member: Make space for stories.

There are some good models for facilitating stories online. The one I learned, and have subsequently taught, is called Story Circle. You can learn the whole process of facilitating a Story Circle online through Roadside Theater's website (www. roadside.org/asset/story-circle-guidelines). In a nutshell, if you've got an hour for every 20 people, arrange chairs in a circle and ask people to put their things away. Review the elements of a story. Remind people that a story is not a diatribe or a rant or a list of bullet points about what we all need to do. Tell people that as others are speaking, there's to be no crosstalk or interaction. Mostly, people will just listen. And then say to the group, "Tell a four or five minute story from your own life that helps us understand who you are and what you value." Or, "Tell a story about a time in your life when you stood up for something you believed in." Or, "Tell a story about a time in your life that you learned something about yourself that changed your selfperception." Do it more than once. Do it to introduce people to one another. Do it to check in. Do it to assess. And every time, be willing not to know what comes next. In my experience, what emerges, if the space is welcoming and authentic, is real life. People's joys and sorrows, their fears and dreams. Everything. Full humanization. And then. . . . who knows? Undertaking such a project means opening up to the terror of not knowing the outcomes, nor having any control over them.

The forces aligned against democratic values and democratic institutions are significant. If the last presidential election is an accurate barometer, almost everyone, regardless of ideology, feels an acute sense of despair at the state of our democracy, either for something perceived as lost or for something promised but never gained. It may seem silly and insignificant compared to the challenges we face, but why not start by telling each other our stories? Why not try to find the true place of the artist? Why not try for full humanization? Why not do something other than more of the same? It's probably too late anyway. We've likely missed the chance. But at this point, truly, what have we got to lose?

What should the future of SLCE look like? I don't know. Frankly, I'm getting less comfortable separating "service" and "civic" from the rest of my life. There are some times that I am with young people called "students." Sometimes I am with young and older people called "staff" and "faculty" and "administration." And sometimes I'm with all ages of folk in "the community." Sometimes I'm with my wife and kids, my brothers and parents. Sometimes I'm alone. And in every space, call it what you will - civic engagement? human engagement? life? I'm just asking myself to show up as an artist. Raw 
and vulnerable and powerful and real. I'm trying to recognize reason's limits and make more room for mystery and questioning. I'm trying to connect to what Beuys' called the "invisible energies with which we have lost contact."

I'm trying to balance the reason-oriented training I received in graduate school with what I learned in acting school: that life comes down to listening and responding. Truly listening and honestly responding. I respond because I have the ability. I am response-able, like all of us. Able to respond to reality, response-able for how the next moment is shaped, for imagining possibilities the status quo proclaims impossible

I'm trying to sing, and I don't mean figuratively. I'm actually trying to bring song into my staff meetings and into my classes and partnerships, because it feels good if you let it. And it can make you cry even when you try to stop it. And maybe if we all cried, something new would emerge. It would definitely change the trajectory of the gen. ed. meeting!

I'm trying to laugh freely when it strikes me.

When I feel embarrassed or scared, I'm trying to say so.

When I start crying I'm trying not to hide.

I'm trying to be a real human.

I'm trying to find the true place of the artist.

I'm trying to stay with the grief.

\section{References}

Brueggemann, W. (2001). The prophetic imagination (Second ed.). Minneapolis, MN: Fortress Press.

Giroux, H. A. (2011). Zombie politics and culture in the age of casino capitalism. New York: Peter Lang.

Tisdall, C. (1979). Joseph Beuys. New York: Thames and Hudson.

Zlotkowski, E. (1995). Does service-learning have a future? Michigan Journal of Community Service Learning, 2, 123-133.
Author

KEVIN BOTT (kevin.bott@wagner.edu) is dean for civic engagement at Wagner College in New York City. For six years prior, he served as the associate director and director for cultural organizing at Imagining America: Artists and Scholars in Public Life. An actor and director by training, Kevin is interested in the power of collaborative theatermaking to cultivate the arts of democracy. He is the founder of Ritual 4 Return, a 12-week program for formerly incarcerated men making the transition back to their communities from prison; and The D.R.E.A.(M. $)^{3}$ Freedom Revival, a participatory, musical "tent revival" celebrating freedom and democracy. He is currently developing a performance art project about grief. 